\title{
OPERATIONAL WEAR OF THE NECK OF SPINDLE COATING IN COOPERATION WITH YARN
}

\section{ZUŻYCIE EKSPLOATACYJNE SZYJKI OKŁADZINY WRZECION PRZĘDZALNICZYCH PRZY WSPÓŁPRACY Z PRZĘDZA}

\begin{abstract}
The article presents results of research on the operating time of the neck of spindle coating with collapse balloon crown of a ring spinning frame in cooperation with yarn under industrial conditions in the form of histograms. Adopting the change of the diameter of the cylindrical part of the neck of spindle coating is the wear criterion $\Delta d \geq 0,5 \mathrm{~mm}$. The assessment of the spindle neck operating time was performed in cooperation with a mixture of fibres: $70 \div 80 \%$ wool fibres with the addition of $10 \div 20 \%$ of polyester fibres, which causes the greatest wear. The research included measurements with the use of the metric method of the wear of the neck coating of a spindles made of the EN AW-2024 alloy (AlCu4Mg1), which were subjected to finishing operation with abrasive cloth, grain number 80, and then 150 and polished with desilted sandpaper and, in the second variant - they were subjected to burnishing. In addition, roundness deviations of the cylindrical part of the neck of spindle coating were measured at equal distances from face of the crown, using a Talyrond 365 roundness tester. Next, on the basis of the roundness outlines obtained, an outline of the cylindricity of the neck of spindle coating burnished before and after the operating time was prepared. Also, measurements of the topography of the surface of the neck of spindle coating were performed before and after the operating time. An analysis of the cylindricity outline and the surface topography confirms that the outer surface of the surface layer along the length and circumference of the neck of spindle coating in cooperation with yarn is subject to uneven wear. The assessment of the topography of the wearing surface and micro-photographs of the side surface of the helical groove lead to the conclusion that the wear of the neck of spindle coating made of the AlCu $4 \mathrm{Mg} 1$ occurs mostly as a result of abrasive wear.
\end{abstract}

Keywords: ring spinning frame, collapse balloon spindle, operational wear.

\begin{abstract}
W artykule zamieszczono wyniki badań czasu pracy szyjki okładziny wrzecion z nasadka antybalonowa przędzarki obraczkowej przy wspótpracy z przędza, $w$ warunkach przemysłowych, $w$ postaci histogramów. Przyjmując jako kryterium zużycia zmiane średnicy, częśsi walcowej, szyjki oktadziny $\Delta d \geq 0,5 \mathrm{~mm}$. Ocenę czasu pracy szyjki przeprowadzono przy wspótpracy z mieszanka

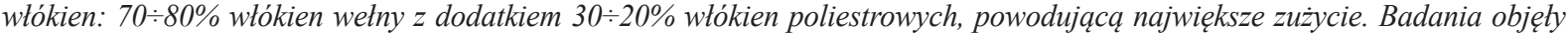
pomiary, metoda metryczna, zużycia szyjki okładziny wrzecion wykonanych ze stopu EN AW-2024 (AlCu4Mg1) poddanych obróbce wykończeniowej przez szlifowanie płótnem ściernym o numerze ziarna 80, a następnie 150 oraz polerowanie papierem ściernym odmulonym, jak również $w$ drugim wariancie - operacji nagniatania. Ponadto wykonano pomiary odchyłki okragłości części walcowej szyjki okładziny, w równych odległościach od czoła nasadki, za pomoca okragtościomierza Taylrond 365. Następnie na podstawie uzyskanych zarysów okrągtości sporządzono zarys walcowości szyjki okładziny wrzeciona nagniatanej przed i po czasie eksploatacji. Wykonano również pomiary topografii powierzchni szyjki okładziny wrzecion przędzalniczych, przed $i$ po okresie eksploatacji. Analiza zarysu walcowości i topografi powierzchni potwierdzaja, że powierzchnia zewnętrzna warstwy wierzchniej, na długości i obwodzie szyjki oktadziny, przy wspótpracy z przędza ulega nierównomiernemu zużyciu. Ocena topografii powierzchni zużycia oraz mikrofotografii powierzchni bocznej rowka śrubowego skłaniają do stwierdzenia, że zużycie szyjki okladzin wrzecion ze stopu AlCu4MgI następuje przede wszystkim w wyniku zużycia ściernego.
\end{abstract}

Stowa kluczowe: przędzarka obrączkowa, wrzeciono z nasadka antybalonowa, zużycie eksploatacyjne.

\section{Introduction}

In ring spinning frames for collapse balloon spinning, there are parts, which come into direct contact with the yarn (the fibre stream), including guides, collapse balloon crowns, necks of spindle coating etc. [5]. The working surface of these parts should meet at least three conditions:

- it should be characterised by a low coefficient of friction in cooperation with yarn, which mostly depends on the stereometric structure of this surface, which results from the production method [11];
- it should not generate electrostatic loads and it should not develop electrostatic charges in the yarn;

- it should be sufficiently resistant to wear and accidental impact.

The results of the research presented in this article are continuation of work on the wear of metal-yarn tribological pairs. In the study [8], observations and measurements of wear of the neck of spindle coating with collapse balloon crown, made of the EN AW-2024 (AlCu4Mg1) alloy which were subjected to finishing operation with abrasive cloth, grain number 80 , and then 150 and polished with sandpaper. The wear of the neck of spindle coating was assessed under industrial conditions in cooperation with two kinds of fibre mixtures: $70 \div 80 \%$ of

(*) Tekst artykułu w polskiej wersji językowej dostępny w elektronicznym wydaniu kwartalnika na stronie www.ein.org.pl 
wool fibres with the addition of $30 \div 20 \%$ of polyester fibres and $90 \%$ of wool fibres with the addition of $10 \%$ of polyamide and $100 \%$ of wool fibres. In the study [9], wear of the neck of spindle coating subject to two kinds of finishing: in the first variant burnishing and in the second variant - burnishing and next hard anode oxidation and grinding with PS 20 corundum sandpaper, grain number 600 . The wear of the neck of spindle coating was assessed under industrial conditions in cooperation with three kinds of fibre mixtures (the composition of mixtures is presented in Table 1 [9]). On the basis of the performed research and observations, it was concluded that the greatest wear of the neck of spindle coating occurs in cooperation with a yarn, which is a mixture of: $70 \%$ of wool fibres with the addition of $30 \%$ of polyester fibres.

Therefore, the aim of the research and the results published was to define the influence of the finishing, e.g. grinding, polishing and burnishing on the operating time of the neck of spindle coatings made of the EN AW-2024 alloy ( $\mathrm{AlCu} 4 \mathrm{Mg} 1)$ in cooperation with the mixture of fibres: $70 \div 80 \%$ of wool fibres with the addition of $30 \div 20 \%$ of polyester fibres.

\section{Methodology of assessment of the wear of the neck of spindle coating with collapse balloon crown}

160 spinning spindles were made and installed on the G-7A ring spinning frame (Fig. 1), in which the neck of coating was finished by:

- grinding with corundum sandpaper HTJ - 13 - 3, grain number 80 , and next with grain number 150 and polished with desilted sandpaper with the following parameters: $v_{c}=3,11 \mathrm{~m} / \mathrm{s}$ and the unit pressure $p_{n} \approx 0,015 \mathrm{MPa}$.

- burnishing with a disc with $d_{k}=40 \mathrm{~mm}$ and the surface rounding radius with an axial section $r_{k}=9 \mathrm{~mm}$, with the clamping force of $F_{n}=0,30 \mathrm{kN}$, the feed rate $f_{n}=0,10 \mathrm{~mm} / \mathrm{r}$, the burnishing rate of $v_{n}=2,07 \mathrm{~m} / \mathrm{s}$ and lubrication with machine oil 10 $[10,12]$.

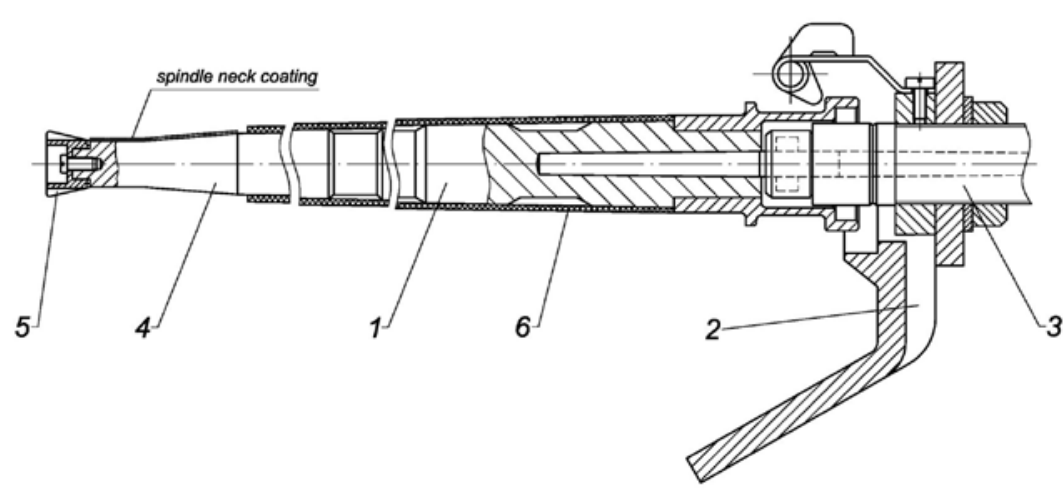

Fig. 1. A complete spindle with collapse balloon crown of the PG-7A ring spinning frame: 1 spindle coating, 2 - brake, 3 - bearing insert, 4 - spindle neck made of the AlCu $4 \mathrm{Mg} 1$ alloy, 5 - crown, 6 - bobbin $[8,9]$

Tests of the wear of the necks of spindle coating with collapse balloon crown in cooperation with yarn were conducted using the metric method [2] on a ring spinning frame under production conditions. Wear measurements while spinning mixtures, as described in Table 1, were performed at 3-month time intervals using a specially adapted micrometer with a range from 0 to $25 \mathrm{~mm}$ with an elementary graduation of $0,002 \mathrm{~mm}$. The wear value $\Delta d$ was defined as a difference between the initial diameter and the lowest value of the diameter of 5 measurements of the cylindrical part of the neck of coating. The diameter was measured every $60^{\circ}$ at a distance of $9 \mathrm{~mm}$ from face of the crown. Due to the fact that 5 to $7,5 \%$ of all spindle coatings undergo wear in the form of the helical groove, a change in the diameter of the neck of spindle coating was adopted as the criterion of wear - and also of the spindle replacement $\Delta d \geq 0,5 \mathrm{~mm}$.
Table 1. Types of yarn spun on the ring spinning frame, their characteristics and percentage of their processing time

\begin{tabular}{||l|c|c|c|c|}
\hline Type of processed material & $\begin{array}{c}\text { Linear mass of } \\
\text { the yarn, } \\
\text { tex }\end{array}$ & $\begin{array}{c}\text { The number of yarn } \\
\text { turns per 1 metre, } \\
1 / \mathrm{m}\end{array}$ & $\begin{array}{c}\text { The number of } \\
\text { spindle rotations, } \\
\text { rpm }\end{array}$ & $\begin{array}{c}\text { Percentage time of } \\
\text { their processing, } \\
\%\end{array}$ \\
\hline Polyester $30 \%+$ wool $70 \%$ & $100 ; 125$ & $390 ; 360$ & $9500 \div 10000$ & 77.6 \\
\hline Polyester $20 \%+$ wool $80 \%$ & 150 & 280 & 8500 & 22.4 \\
\hline
\end{tabular}

Moreover, to assess the wear of necks of spindle coatings, measurements of the roundness deviations (scanning the diameter of the neck of coating) were performed using the Taylrond 365 roundness meter by the Taylor Hobson company, equipped with a measuring tip ended with a ball with a radius of $R_{k}=0,5 \mathrm{~mm}$. Roundness deviations were measured at a distance of $1 \div 16 \mathrm{~mm}$ from the crown at crosssections at distances of $0,5 \mathrm{~mm}$ before and after the operating time of the spindle. Next, as a result of employing a strategy of obtaining roundness outlines, an outline of the cylindricity of the spindle neck burnished before and after the operating was prepared [1].

The shape of the helical groove was measured in the perpendicular direction to the groove using the Form Talysurf 120 contour measurement system by the Taylor Hobson company, equipped with a wide-range head with a measuring tip with a roundness radius of $r_{p}=20 \mu \mathrm{m}$. The outline of the shape of the groove was determined at the following distances from face of the crown: $1,0 \mathrm{~mm}$ and next every $2,0 \mathrm{~mm}$ up to the distance of $17,0 \mathrm{~mm}$, and next at the following distances: 20,$0 ; 25,0 ; 30,0$ and $35,0 \mathrm{~mm}$.

To assess the influence of yarn movement to the roughness of the surface of the neck of spindle coating also measurements of the surface topography at a distance of approx. $9 \mathrm{~mm}$ below the crown were carried out. The following parameters of $3 \mathrm{D}$ surface roughness were considered $[6,13,14]$ (before and after the operating time of the spindles): amplitude parameters of the surface - arithmetical mean height of the surface $S_{a}$, root mean square height of the surface $S_{q}$, maximum peak height of the surface $S_{p}$, maximum pit height of the surface $S_{v}$, maximum height of the surface $S_{z}$, skewness of the surface $S_{s k}$ and the kurtosis of the surface $S_{k u}$ and spatial parameters: core height $S_{k}$, reduced peak height $S_{p k}$, reduced dale height $S_{v k}$, material ratio (peaks ratio of the area of the material) $S_{m r l}$, material ratio (dales ratio of the area of the material) $S_{m r 2}$, volume of the material $S_{a 1}$ and volume of deep dales $S_{a 2}$. Moreover, for the surface of the neck of spindle coating after the burnishing operation before and after operation, comprehensive characteristics of the stereometric structures of the surface including: a topographic map of the surface, an isophyse map, a histogram of the distribution of surface ordinates and the areal material ratio curve. The selected $3 \mathrm{D}$ roughness parameters were measured using the New Form Talysurf 2D/3D 120 contour measurement system by the Taylor Hobson company using Ultra Surface 5.21 and TalyMap Platinium 5.1.1 software. During roughness measurements, value of the sampling length $l_{r}=0,25$ or $0,80 \mathrm{~mm}$ was used (the sampling length was selected automatically by the software), the number of registered points $N_{x}=10000$, the sampling step $\Delta_{x}=0,308 \mu \mathrm{m}$, the fillet radius of the diamond gauging point $r_{t i p}=2,0 \mu \mathrm{m}$, the pressure 
of the gauging point $F_{k p}=1,0 \mathrm{mN}$, the feed rate of the gauging point $v_{o s}=1,0 \mathrm{~mm} / \mathrm{s}$ and a Gaussian filter. Topography measurements were performed to surfaces with the following dimensions $3,08 \mathrm{~mm} \times 3,0$ $\mathrm{mm}$ at $5 \mu \mathrm{m}$ distances.

Microhardness measurements were conducted using the Vickers method on oblique microsections made at an angle of $4^{\circ} 30^{\prime}(0,0785$ rad), using a microhardness tester by the Leitz Wetzlar company with the indenter load of $0,49 \mathrm{~N}$.

With the use of a scanning electron microscope (SEM) Jeol-J7, traces of wear of the side surface of the helical groove were observed following the period of yarn friction against the neck of spindle coating, which was approx. 21600 hours.

\section{Wear of the neck of spindle coating with collapse balloon crown during the spinning process}

During the operation of a spindle yarn moving at a speed of $25 \div 35$ $\mathrm{m} / \mathrm{min}$, as a result of local friction caused by insufficiently smooth movement ("skipping") from one notch of the crown to the neighbouring one (Fig. 2a), and often as a result of yarn being "held" by one of the crown's notches, excessive wear of the neck of spindle coating occurs. This wear is manifested by the formation of approx. $2 \mathrm{~mm}$-wide and over $1 \mathrm{~mm}$-deep helical grooves in approx. 5 to $7,5 \%$ cases (Fig. 2b) after cooperation with yarn for at least over 10 thousand hours. These grooves prevent smooth movement of yarn over the neck of coating and, as a result, cause a greater number of cases of breaking the yarn.

a)

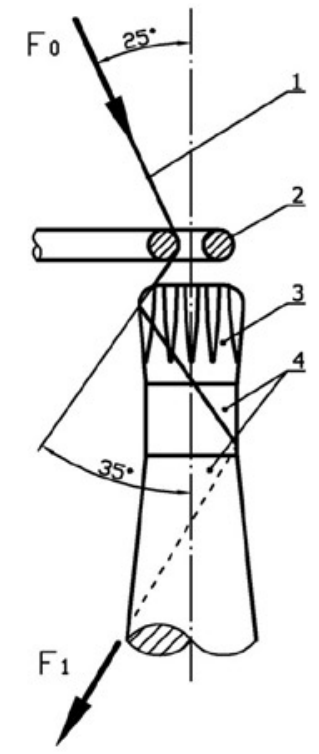

b)

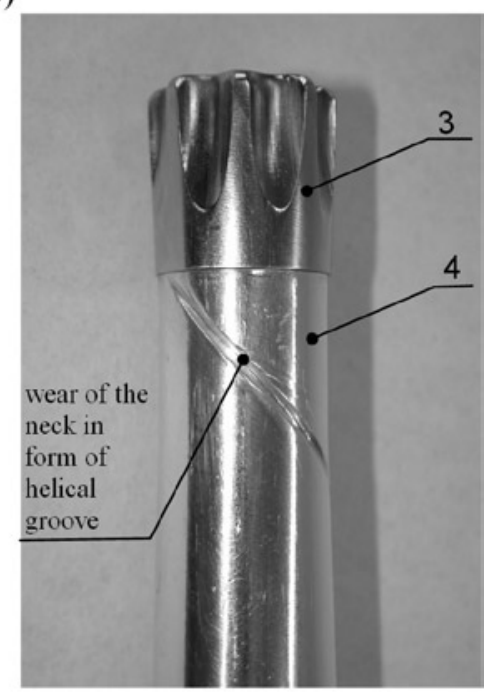

tial, Weibull and logarithmic-normal distribution. The most advantageous fit was obtained for the logarithmic-normal distribution. The hypothesis about the compliance between empirical and theoretical distribution for both cases was verified using a chi-square test at the significance level of 0,05 .

It results from histograms, that the average operating time $\tau$ of grinded and polished necks of spindle coatings, in cooperation with yarn being a mixture of $70 \div 80 \%$ wool fibres with the addition of $10 \div 20 \%$ of polyester fibres, was $\tau=9591$ work hours. The operating time of burnished necks of spindle coating was extended by approx. $27,3 \%$ and it was $\tau=12211$ work hours. This should be explained by a greater hardness of the near-surface zone of the surface layer obtained by burnishing, as compared to the hardness of the near-surface zone of grinded and polished neck and a considerably greater thickness of this layer, in addition to a flat peak structure of the surface with a large share of material carrying capacity.

The influence of the finishing method of the necks of spindle coating and the operating time on the wear $\Delta d$ is presented in Figure 5. The necks of spindle coating, which were finished by burnishing, were characterised by lower wear. During the first phase of abrasive wear, it should be explained by a more advantageous contour of irregularities of burnished surfaces, lower values of roughness parameters and a larger share of material-carrying capacity. During the second phase (after grinding off irregularities), it can be explained by greater hardness of the near-surface area of the top layer by approx. $400 \mathrm{MPa}$, as compared to the hardness of this zone of grinded and polished neck and a significantly greater thickness of this layer equal to approx $80 \mu \mathrm{m}$ (Fig. 6) and its internal compression stresses [3, 4, 12].

The shape of burnished cylindrical surface of the neck of spindle coating situated directly under the crown before and after an operating time of approx. 21600 work hours is presented in Figure 7. Before the operation, the cylindrical part of the neck of coating was characterised by roundness deviation within the range of $3,37 \div 9,88 \mu \mathrm{m}$ at the individual cross-sections while the cylindricity deviation was $17,21 \mu \mathrm{m}$. During the operating time of approx. 21600 work hours, the roundness deviation increased along the neck of coating from approx. 26,5 to approx. 162,0 times and it fell within the range of $261,69 \div 769,30 \mu \mathrm{m}$, while the cylindricity deviation was $849,71 \mu \mathrm{m}$ [9].

The results of measurements of selected $3 \mathrm{D}$ roughness parameters of the necks of burnished spindle coating before and after the operating time are presented in Table 2.

The values of parameters of 3D surface roughness, such as $S_{a}, S_{q}, S_{p}, S_{v}, S_{z}$ of the neck of spindle coating for five measurements after the burnishing operation, are almost identical, while the values of the other parameters are very similar. For burnished surfaces, the $S_{s k}$ skewness of the surface falls within the range of $0,205 \div 0,453$, while the kurtosis falls within the range of $S_{k u}=3,10 \div 4,35$, which shows that the distribution of ordinates of surface peaks is close to a normal distribu-

The wear of the neck of coating is enhanced by dead particles (of grass, bark, straw) found in the stream of fibres, especially in wool, and quite often dust particles stuck to wool fibres [7].

A histogram of the operating time of the neck of spindle coating with collapse balloon crown after grinding and polishing, in cooperation with yarn being a mixture of $70 \div 80 \%$ of wool fibres with the addition of $30 \div 20 \%$ of polyester fibres, is presented in Figure 3 . The necks of spindle coating after burnishing are presented in Figure 4. Histograms of the operating time of the necks of spindle coating were identified by means of the following distributions: normal, exponen- tion $\left(S_{s k}=0, S_{k u}=3\right)$. The movement of the stream of fibres (yarn) over the neck of coating of a burnished spindle makes its surface glossy after a very short contact with the yarn and the values of roughness parameters, such as $S_{a}$ and $S_{q}$ were generally reduced. While roughness parameters, such as $S_{p}$ and $S_{z}$ increased significantly, while the values of the other parameters were similar. In general, in 5 to $7,5 \%$ of cases, as a result of imperfections of the crown-manufacturing process (generally improper rounding of the notch or tooth), one from teeth of the crown holds the yarn significantly longer than the other ones and its contact with surface of the neck is much longer. As a result, 


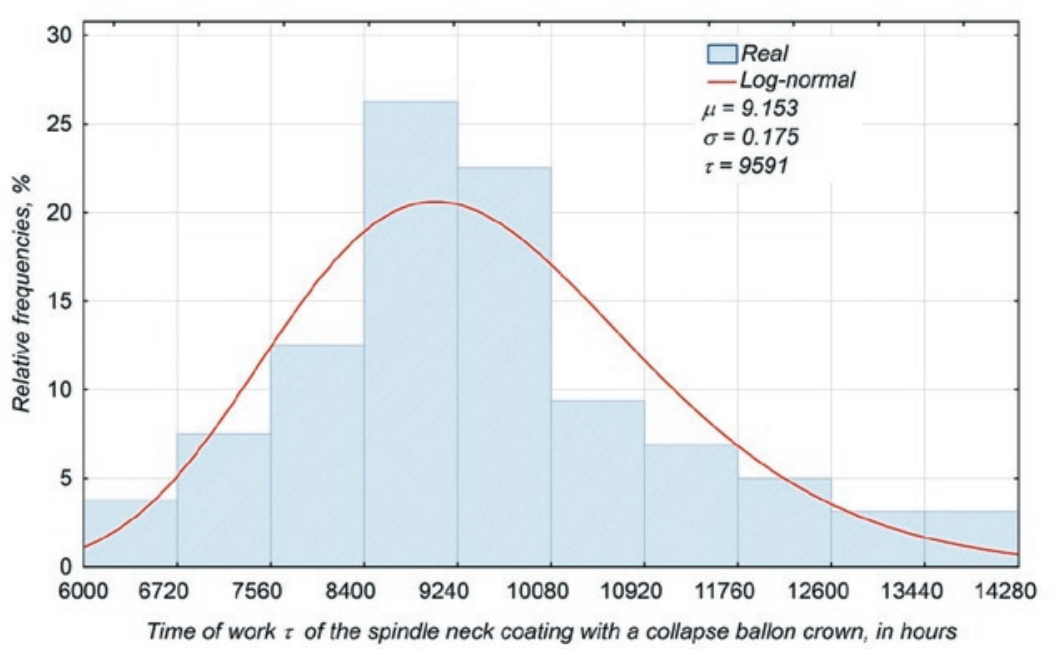

Fig. 3. A histogram of the operating time of grinded and polished necks of spindle coating made of the AlCu4Mgl alloy in cooperation with yarn [8]

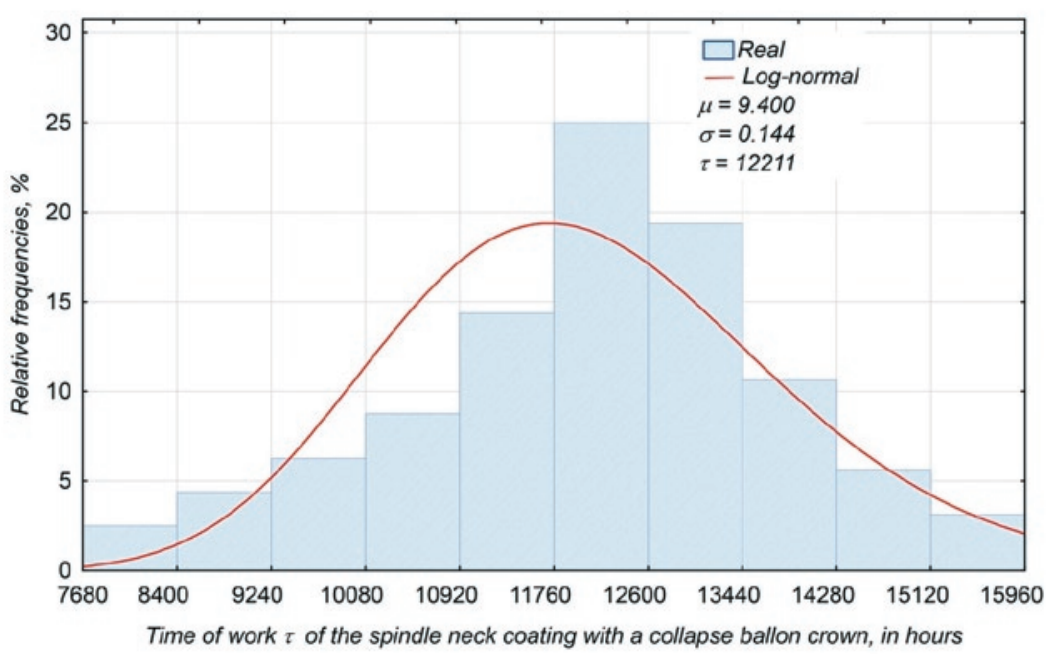

Fig. 4. A histogram of the operating time of burnished necks of spindle coating made of the Al$\mathrm{Cu} 4 \mathrm{Mg} 1$ alloy in cooperation with yarn

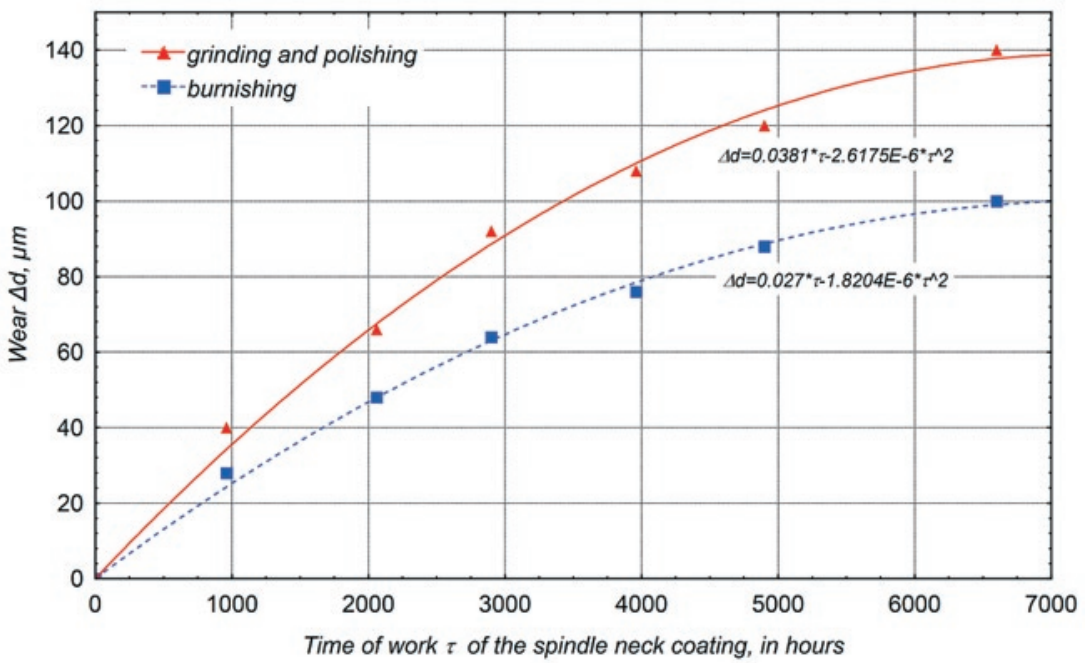

Fig. 5. The influence of the operating time on the wear of the neck of spindle coating with collapse balloon crown for two finishing methods the AlCu4Mgl alloy in cooperation with yarn [8] the majority of the measured 3D roughness parameters of the neck of coating increased significantly after approx. 21600 work hours. For example, the root mean square height of the surface $S_{q}$ of the neck of burnished spindle coating before operation ranged from 0,351 to $0,377 \mu \mathrm{m}$, while after a period of cooperation with yarn of 21600 work hours, it was $-S_{q}=0,446 \div 0,723$ $\mu \mathrm{m}$. The maximum height of surface peaks before the operation was $S_{p}=1,33 \div 1,38 \mu \mathrm{m}$, while after the cooperation period with yarn, it was approx. 21600 work hours $-S_{p}=2,64 \div 6,16 \mu \mathrm{m}$. The $S_{s k}$ and $S_{k u}$ roughness parameters changed the most. The skewness of the surface $S_{s k}$ of the neck of burnished coating fell within the range from 0,205 to 0,453 before the operation, while the kurtosis $S_{k u}$-ranged from 3,10 to 4,35 , while after the period of cooperation with yarn of approx. 21600 work hours (for worn surfaces) $-S_{s k}=-1,86 \div 0,999$, and $S_{k u}=6,95 \div 15,30$. For considerably worn surfaces near a helical groove, the skewness of the surface $S_{\text {sk }}$ increased from 2,20 to 4,87 times (the mode of surface peak ordinate distribution distinctly shifts downwards), while the kurtosis $S_{k u}$ - from 1,60 to 2,24 times (which increases the fuzziness of ordinates). The negative value of the skewness of the surface $S_{s k}$ and a value of kurtosis $S_{k u}$, which was higher from 3,5 to 4,9 times, occurred for a worn surface with deep scratches, which were probably formed by cutting broken yarn wrapped around the neck of coating with a sharp tool. Figures 8 and 9 present comprehensive characteristics of 3D roughness of the surface of a burnished neck of coating before and after the operation, which include: a topographic map of the surface, an isophyse map, the distribution of surface ordinates and the areal material ratio curve. The surface topography of the neck of spindle coating after burnishing is characterised by flattened peaks, however, after an operating time of 21600 work hours, the peaks of considerably worn surface are sharp. The maximum peak height of the surface $S_{p}$ after operation (considerably worn) is approx. 4,5 times greater as compared to the maximum height of peaks after burnishing. The parameters of the areal material ratio curve for the neck of coating after burnishing and operation are significantly higher for a considerably worn surface. The core height $S_{k}$ is higher by 1,61 to 1,86 times, the reduced peak height $S_{p k}$ is from 2,32 to 2,74 times higher, while the reduced dale height $S_{v k}$ is from 1,64 to 2,07 times higher, as compared to the value of these parameters for the surface of the burnished neck of coating.

For burnished surfaces of the neck of spindle coating, the values of the volume of the material $S_{a l}$, as well as of the volume of deep dales $S_{a 2}$ are similar; however, the values of $S_{a l}$ for the same measurement are always higher by 2,22 to 3,46 times from the value of $S_{a 2}$. For burnished surfaces, after the operating time of 21600 work hours at a considerably worn place, the values of the volume of the material $S_{a l}$ and the volume of deep dales $S_{a 2}$ are over two times higher than the values of these parameters for surfaces before operation. The value of the material volume $S_{a l}$ was lower than the value of the volume of deep dale $S_{a 2}$ only in one case. This should be explained by damage to the surface of the neck of coating in the form of a relatively deep scratch.

The parameters of 3D surface roughness of the neck of spindle coating after grinding with abrasive 


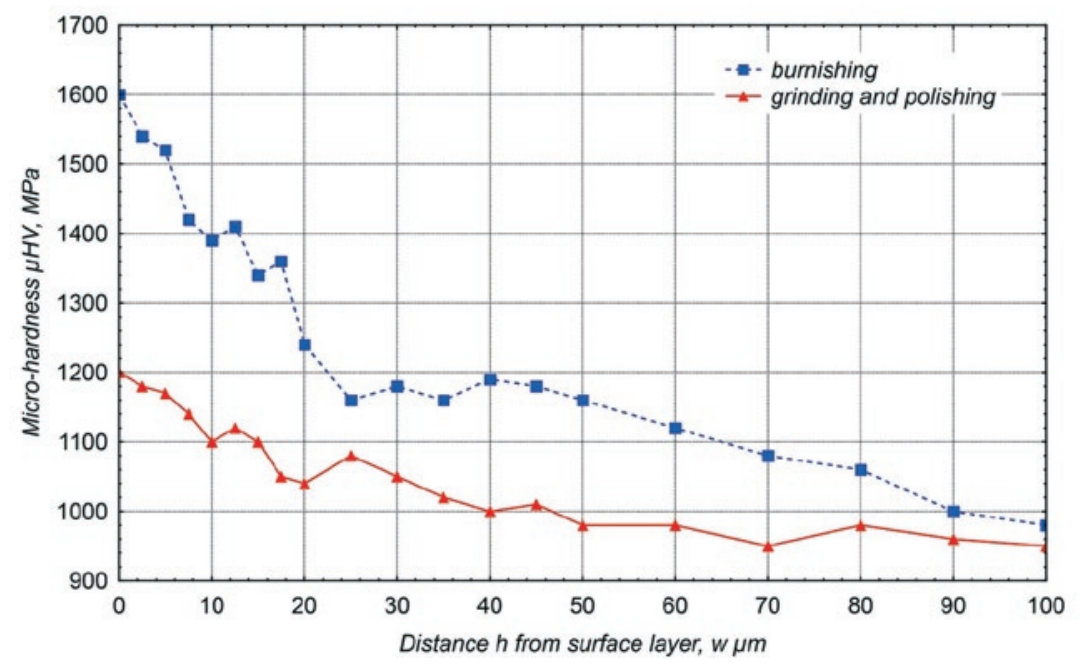

Fig. 6. Distribution of micro-harness in the surface layer of the necks of spindle coating made of the AlCu4Mgl alloy in depth of the surface layer

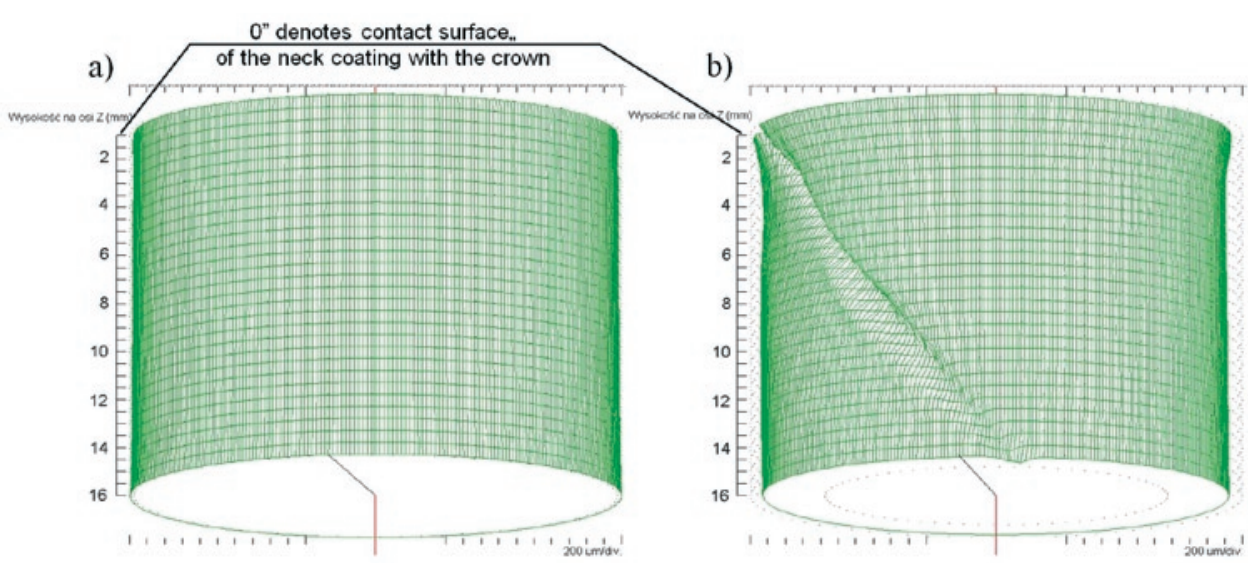

Fig. 7. The shape of the cylindrical part of the spindle neck coating with collapse balloon crown after burnishing. a) before the operation (0 hours in cooperation with yarn); b) after the operation (21 600 hours of cooperation with yarn) [9] Table 2. Values of selected 3D roughness parameters of the neck of spindle coating with collapse balloon crown made of the AlCu4Mg1 after burnishing, before and
after the operating time

\begin{tabular}{|c|c|c|c|c|c|c|c|c|c|c|}
\hline \multirow{2}{*}{$\begin{array}{l}3 \mathrm{D} \text { roughness } \\
\text { parameters }\end{array}$} & \multicolumn{5}{|c|}{ Burnished surface of the neck of coating before operation } & \multicolumn{5}{|c|}{$\begin{array}{l}\text { Burnished surface of the neck of coating after approx. } 21600 \text { work } \\
\text { hours of cooperation with yarn }\end{array}$} \\
\hline & $\begin{array}{l}\text { measure- } \\
\text { ment } 1\end{array}$ & $\begin{array}{l}\text { measure- } \\
\text { ment } 2\end{array}$ & $\begin{array}{l}\text { measure- } \\
\text { ment } 3\end{array}$ & $\begin{array}{l}\text { measure- } \\
\text { ment } 4\end{array}$ & $\begin{array}{l}\text { measure- } \\
\text { ment } 5\end{array}$ & $\begin{array}{l}\text { measure- } \\
\text { ment } 1\end{array}$ & $\begin{array}{l}\text { measure- } \\
\text { ment } 2\end{array}$ & $\begin{array}{l}\text { measure- } \\
\text { ment } 3\end{array}$ & $\begin{array}{l}\text { measure- } \\
\text { ment } 4\end{array}$ & $\begin{array}{l}\text { measure- } \\
\text { ment } 5\end{array}$ \\
\hline$S_{a} \mu \mathrm{m}$ & 0,278 & 0,288 & 0,298 & 0,278 & 0,276 & 0,530 & 0,207 & 0,301 & 0,227 & 0,288 \\
\hline$S_{q^{\prime}} \mu \mathrm{m}$ & 0,359 & 0,364 & 0,377 & 0,358 & 0,351 & 0,723 & 0,267 & 0,446 & 0,294 & 0,374 \\
\hline$S_{p,} \mu \mathrm{m}$ & 1,36 & 1,38 & 1,38 & 1,33 & 1,36 & 6,16 & 2,00 & 2,50 & 2,31 & 2,64 \\
\hline$S_{v}, \mu \mathrm{m}$ & 4,08 & 3,90 & 3,99 & 4,10 & 3,68 & 3,13 & 3,20 & 4,12 & 1,69 & 4,08 \\
\hline$S_{z}, \mu \mathrm{m}$ & 5,44 & 5,28 & 5,37 & 5,43 & 5,04 & 9,29 & 5,20 & 6,62 & 4,00 & 6,72 \\
\hline$S_{s k}$ & 0,205 & 0,350 & 0,453 & 0,280 & 0,399 & 0,999 & 0,496 & $-1,86$ & 0,342 & 0,620 \\
\hline$S_{k u}$ & 4,35 & 3,10 & 4,17 & 4,33 & 3,58 & 6,95 & 4,31 & 15,30 & 4,31 & 4,65 \\
\hline$S_{k^{\prime}} \mu \mathrm{m}$ & 0,800 & 0,887 & 0,924 & 0,831 & 0,846 & 1,49 & 0,635 & 0,875 & 0,700 & 0,840 \\
\hline$S_{p k^{\prime}} \mu \mathrm{m}$ & 0,468 & 0,416 & 0,490 & 0,477 & 0,462 & 1,14 & 0,362 & 0,464 & 0,366 & 0,514 \\
\hline$S_{v k}, \mu \mathrm{m}$ & 0,393 & 0,313 & 0,311 & 0,318 & 0,367 & 0,645 & 0,290 & 0,948 & 0,319 & 0,354 \\
\hline$S_{r 1}, \%$ & 15,5 & 14,1 & 14,5 & 13,9 & 13,6 & 13,2 & 12,3 & 11,0 & 11,5 & 14,3 \\
\hline$S_{r 2}, \%$ & 91,7 & 91,8 & 94,7 & 91,1 & 93,2 & 89,1 & 91,9 & 91,7 & 91,1 & 91,3 \\
\hline$S_{a 1}, \mu \mathrm{m}^{3} / \mathrm{mm}^{2}$ & 36,4 & 29,4 & 35,6 & 33,1 & 31,4 & 75,6 & 22,3 & 25,6 & 21,1 & 36,7 \\
\hline$S_{a 2}, \mu \mathrm{m}^{3} / \mathrm{mm}^{2}$ & 16,4 & 12,9 & 10,28 & 14,1 & 12,4 & 35,1 & 11,8 & 39,4 & 14,1 & 15,4 \\
\hline
\end{tabular}

cloth and polishing with desilted sandpaper were the following: $S_{a}=0,50 \mu \mathrm{m}, S_{q}=0,64 \mu \mathrm{m}, S_{p}=2,74 \mu \mathrm{m}$, $S_{v k}=0,84 \mu \mathrm{m}, S_{r l}=9,07 \%$ and $S_{r 2}=88,87 \%$. As it can be seen, the values of nearly all roughness parameters after grinding and polishing are significantly higher than after burnishing. Only the $S_{p k}$ parameter after the grinding and polishing operation was several times lower than the value of this parameter for burnished surfaces. After the operating time of approx. 14400 work hours, on the other hand, as a result of yarn friction against the neck of coating, the following roughness parameters were slightly reduced: $S_{a}, S_{q}, S_{v}$ and $S_{v k}$, and the following were increased $S_{p}, S_{z}$ and $S_{k}$ [8].

The wear of burnished surface of the neck of coating is uneven, both along the circumference and along the spindle axis (Fig. 7). The movement of the stream of fibres (yarn) along the neck of a burnished spindle coating, if the contact with the yarn is very short, results in its slight wear as regards surface irregularities and is usually manifested by surface glossing. Such a situation occurs when the yarn is on one from the teeth of the crown, and hence at the largest distance from the spindle axis. Then the pressure of the yarn on the neck of coating is the smallest and it lasts the shortest. If the yarn is in cavities of the crown, it fits and adheres to surface of the neck of coating more closely. The yarn pressure on surface of the neck becomes much greater and the time of its contact with surface of the neck is considerably extended. As a result, the intensity of the wear of the neck's surface is greater and cavities are formed; their number for the necks of spindle coatings, which are almost evenly worn, corresponds to the number of teeth on the crown. While for the neck of spindle coating with inappropriately $S_{v}=4,03 \mu \mathrm{m}, S_{z}=6,77 \mu \mathrm{m}, S_{k}=1,97 \mu \mathrm{m}, S_{p k}=0,07 \mu \mathrm{m}$, 

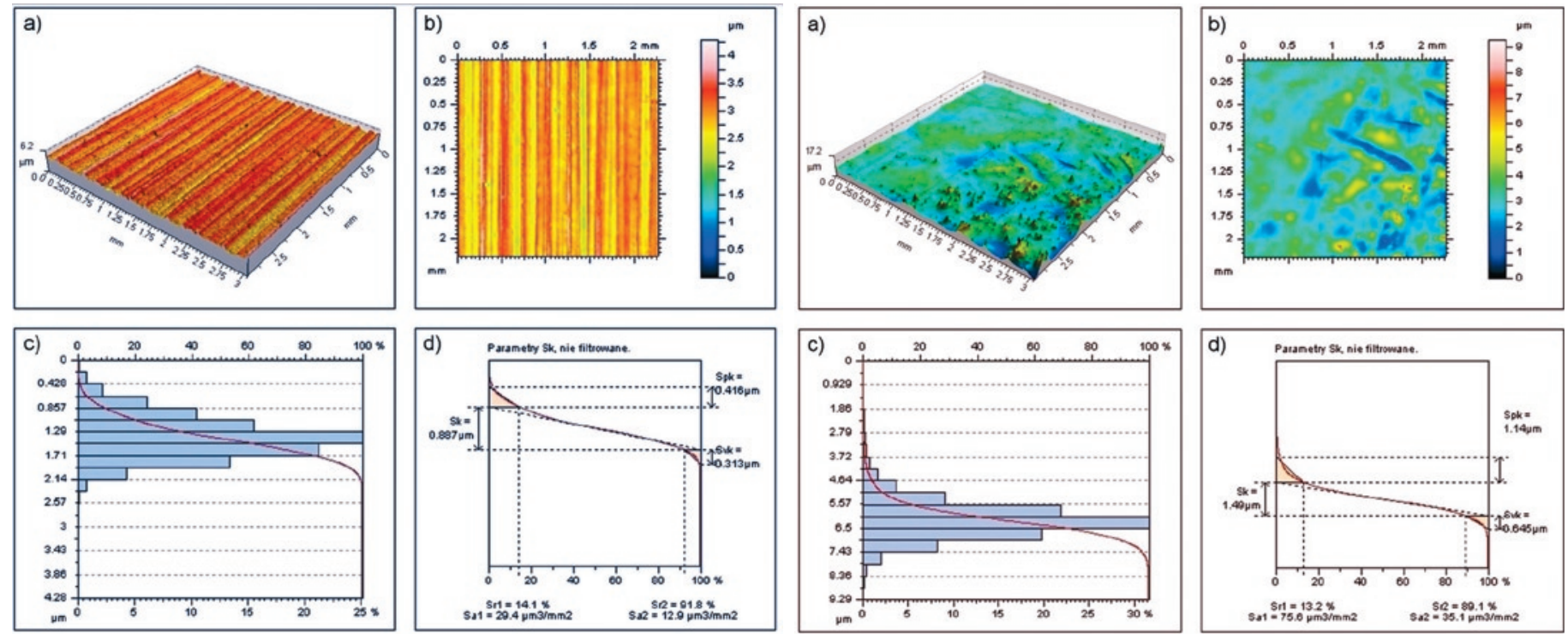

Fig. 8. Image of the stereometric structure of surface of the neck of spindle coating after burnishing: a) topographic map of the surface: $S_{a}=0,288 \mu \mathrm{m}$, $\left.S_{q}=0,364 \mu \mathrm{m}, S_{p}=1,38 \mu \mathrm{m}, S_{v}=2,90 \mu \mathrm{m}, S_{z}=4,28 \mu \mathrm{m} ; b\right)$ isophyse map; c) histogram of surface ordinate distribution; d) areal material ratio curve

Fig. 9. Image of the stereometric structure of surface of the neck spindle coating after burnishing and after cooperation with yarn for approx. 21600 hours: a) topographic map of the surface: $S_{a}=0,530 \mu \mathrm{m}, S_{q}=0,723 \mu \mathrm{m}$, $\left.S_{p}=6,16 \mu \mathrm{m}, S_{v}=3,13 \mu \mathrm{m}, S_{z}=9,29 \mu \mathrm{m} ; \mathrm{b}\right)$ isophyse map; c) histogram of surface ordinate distribution; $d$ ) areal material ratio curve

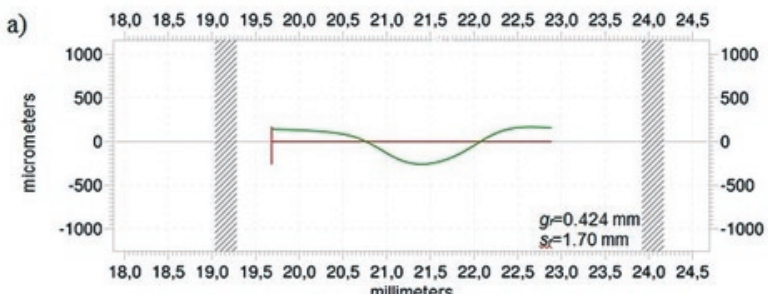

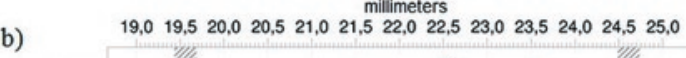

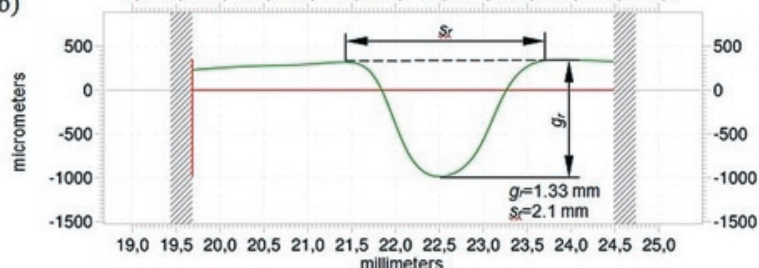

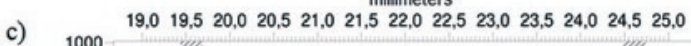

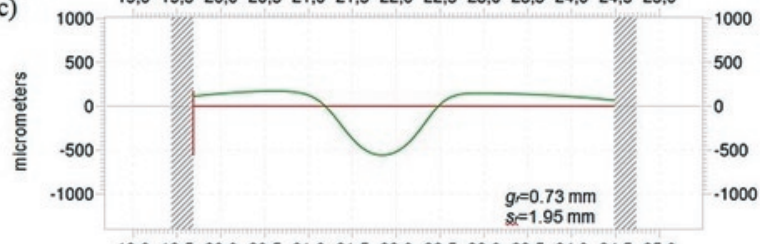

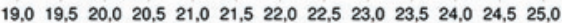

$\begin{array}{lllllllllllll}19,0 & 19,5 & 20,0 & 20,5 & 21,0 & 21,5 & 22,0 & 22,5 & 23,0 & 23,5 & 24,0 & 24,5 & 25,0\end{array}$

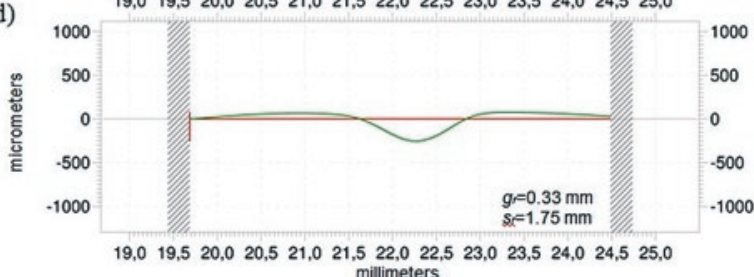

Fig. 10. An outline of the helical groove in a cross-section perpendicular to the outline of the helical groove at a distance of: a) 1,0 mm; b) 9,0 $\mathrm{mm}$; c) $17,0 \mathrm{~mm}$; d) $25,0 \mathrm{~mm}$ from face of the crown.

rounded edge of one from the teeth of the crown, the number of cavities at a certain distance from its face is lower by one or two cavities. This is caused by yarn not moving smoothly along the teeth of the crown (the yarn is held by such a tooth). As a result, a helical groove

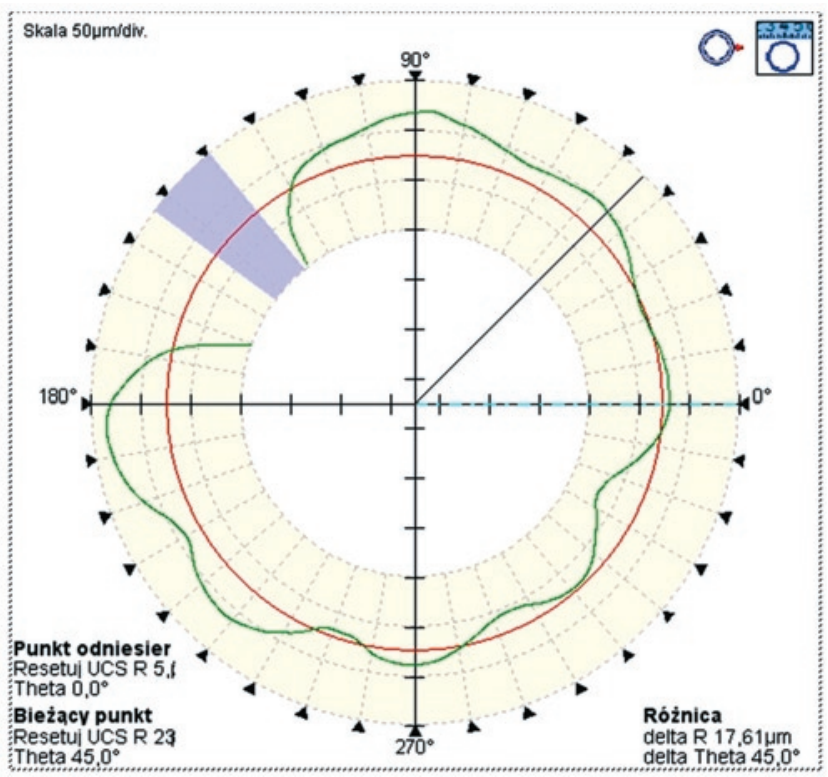

Fig. 11. The shape of burnished neck of spindle coating after an operating time of approx. 21600 work hours (transverse cross-section at a distance of $9 \mathrm{~mm}$ from face of the crown) [9]

is formed along an approx. $45 \mathrm{~mm}$-long section of the neck of coating with a considerable width and variable depth. Figure 10 presents shapes of the groove at a distance of 1,$0 ; 9,0 ; 17,0$ and $25,0 \mathrm{~mm}$ from the face of the crown in a cross-section perpendicular to the helical groove outline. The greatest wear in the form of the helical groove with a depth of approx. $g_{r}=1,33 \mathrm{~mm}$ and a width of $s_{r}=2,10 \mathrm{~mm}$, in the tested batch of spindles, occurred at a distance of approx. $9 \mathrm{~mm}$ from the face of the crown (Fig. 10b). The shape of burnished neck of spindle coating after an operating time of approx. 21600 work hours in a cross-section perpendicular to axis of the spindle neck at distance of $9 \mathrm{~mm}$ from the face of the crown is presented in Figure 11.

Figure 12 presents micro-photographs of the worn surface of the side wall of the helical groove after a period of friction of the yarn against the neck of coating of approx. 21600 work hours. 

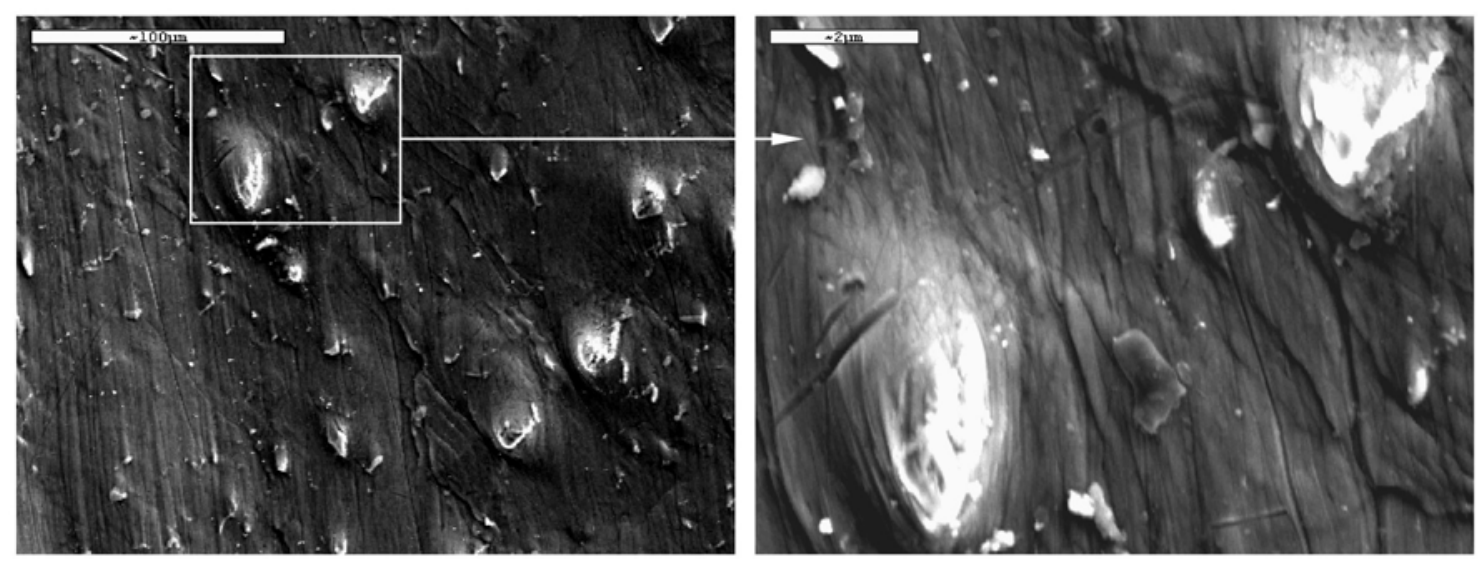

Fig. 12. Micro-photograph of the worn surface of the side wall of the helical groove after cooperation with yarn for approx. 21600 work hours (at a distance of approx. $9 \mathrm{~mm}$ from face of the crown)

The hypothesis that the loss of material along the circumference of the neck of spindle coating with collapse balloon crown in the form of cavities with a helix and, at the same time, a reduction in its diameter, is caused by separating small volumes of the material as a result of continuous impact of yarn fibres and periodical impact of solid particles in the form of grass, bark, straw and often dust particles, which are present in the stream of fibres moving together with it. These particles are pressed against surface of the neck of coating with variable force as a result of variable tension of the yarn caused by its cyclic entering and leaving the notches of the crown and a variable position of the axis of the spindle ended with the crown during the rotational motion. By analogy with the operation of grinding with unrolling sandpaper, it can be adopted that solid particles play the role of micro-blades, which cause cavities of various depths to form over a long period of time.

The number of these cavities at a distance of approx. $9 \mathrm{~mm}$ from face of the crown is lower by one or two cavities for the necks of worn spindles than the number of teeth on the crown. In the authors' opinion, abrasive wear is of dominant importance when the friction between the yarn and the surface of the neck of spindle coating with collapse balloon crown occur.

Two groups of factors influence the intensity of this wear: the first one - connected with the stereometric structure of the surface and physical properties of surface layer of the neck of spindle coating and the other one connected with the characteristics of the spinning process, i.e. the type of processed mixture, tension and the rate of yarn movement. The outline of flat peak irregularities of the surface and, in this way, a greater material-carrying proportion increases the contact area with the yarn and with identical spinning conditions, cause lower unit pressure and lower wear. Similarly, an increase in the hardness of the surface layer and compression stresses reduce the wear.

\section{Summary}

The use of burnishing as the finishing of the neck of spindle coating with collapse balloon crown made of the EN AW-2024 alloy (Al$\mathrm{Cu} 4 \mathrm{Mg} 1$ ), resulted in an increase in wear resistance by over $27 \%$ in cooperation with yarn being a mixture of: $70 \div 80 \%$ of wool fibres with an addition of $30 \div 20 \%$ of polyester fibres as regards grinded and polished necks of spindle coating. It is caused by a different stereometric surface of burnished surfaces, higher microhardness (by $400 \mathrm{MPa}$ ) of the surface layer after burnishing, and internal compression stresses $[3,12]$. This wear was manifested by the formation of a helical groove with a variable width and depth, a stroke of approx. $50 \mathrm{~mm}$, over a length of approx. $45 \mathrm{~mm}$ of the neck of spindle coating starting form face of the crown. After cooperating with yarn for 21600 work hours, the greatest wear occurred at a distance of approx. $9 \mathrm{~mm}$ from face of the crown and it was characterised by a groove, which was $2,10 \mathrm{~mm}$ wide and approx. 1,33 $\mathrm{mm}$ deep. This groove prevents smooth movement of the yarn over the neck of coating and, as a result, causes a greater number of cases of breaking the yarn.

The assessment of the surface of the neck of spindle coating with a manufacturing fault at the place of wear shows that after an operating period of 21600 hours, nearly all roughness parameters were increased, e.g. root mean square height of the surface $S_{q}$ - over 2,0 times, the maximum peak height of the surface $S_{p}$ over 4,5 times, the reduced peak height $S_{p k}$ approx. 2,5 times and the reduced dale height $S_{v k}$ from approx. 1,8 to over 2,0 times.

\section{References}

1. Adamczak S.: Pomiary geometryczne powierzchni. Zarysy kształtu, falistość i chropowatość. WNT, Warszawa 2008.

2. Kragelsky I.V., Alisin V.V.: Tribology - Lubrication, Friction and Wear, John Wiley \& Sons Inc., 2005.

3. Kukiełka L.: Theoretical and experimental foundations of surface roller burnishing with the electrocontact heating. Book of Mechanical Engineering. Technical University of Koszalin 1994.

4. Kukiełka L., Geleta K., Kukiełka K.: Modelling of Initial and Boundary Problems with Geometrical and Physical Nonlinearity and its Application in Burnishing Processes. Steel Research International Special edition, 2012, Publishing Company Wiley - VCH Verlag GmbH\&Co. KGaA, Weinheim ISBN 978-3-514-00774-0, pp. 1375-1379.

5. Lawrence C.A.: Fundamentals of Spun Yarn Technology. CRC Press, Leeds 2003, http://dx.doi.org/10.1201/9780203009581.

6. Oczoś K.E., Liubimov V.: Struktura geometryczna powierzchni, Editorial Office of the Technical University Rzeszów 2003.

7. Płonka S., Hajduga M., Jędrzejczyk D.: The Wear Model Prognose of Tribologie Coupe - the Steel Guide - Yarn. Fibres \& Textiles in Eastern Europe 2007; 15, 2: 54-57.

8. Płonka S., Hajduga M.: Assesing the Wear of Spindle Neck Coating Made of AlCu4Mg1 Alloy of Ring Spinning Spindles with an Antiballoon Crown, Fibres \& Textiles in Eastern Europe 2008; 16, 3: 27-32. 
9. Płonka S.: Effect of Surface Treatment on Wear of Spindle-Neck Coating with Collapse Balloon Crown. Fibres \& Textiles in Eastern Europe 2013; 21, 1: 48-55.

10. Płonka S.: Metody oceny i wyboru optymalnej struktury procesu technologicznego. Design and Exploitation of Machines 48, Scientific Dissertations 31, Branch of Łodz Technical University, Bielsko-Biała 1998.

11. Płonka S., Przybyło S.: Wpływ struktury stereometrycznej powierzchni warstwy tlenkowej na kinetyczny współczynnik tarcia przędzy. Tribologia - Tribology, 38(2007)6, 151-163.

12. Przybylski W.: Technologia obróbki nagniataniem. WNT, Warszawa 1987.

13. Stout K.J., Blunt L.: Three Dimensional Surface Topography, Penton Press London 2000.

14. ISO 25178-2:2012 (E) - Geometrical product specifications (GPS) - Surface texture: Areal - Part 2: terms, definitions and surface texture parameters.

Stanisław PŁONKA

Department of Manufacturing Technology and Automation University of Bielsko Biała

43-309 Bielsko-Biała, ul. Willowa 2

\section{Andrzej ZABORSKI}

Częstochowa University of Technology

Department of Mechanical Technologies

Częstochowa University of Technology

42-201 Częstochowa, ul. Armii Krajowej 21

E-mail: splonka@ath.bielsko.pl, zaborski@itm.pcz.czest.pl 